\title{
Influence of Guidance and Counseling on Choice of Business Subjects Among Secondary School Students in Gombe State
}

\author{
Dr Adamu Ibrahim ${ }^{1} \quad$ Dr Jibril, A. Haruna ${ }^{2} \quad$ Dr. Adukwu, Achem Emmanuel ${ }^{3}$ \\ 1.Faculty of educational Technology \\ Abubakar Tafawa Balewa University Bauchi, Nigeria \\ 1.Faculty of Administration \\ Nasarawa state University, Keffi \\ Nasarawa state, Nigeria \\ Faculty of Educational Technology, \\ Modibbo Adama University Of Technology (Mautch) Yola, Nigeria
}

\begin{abstract}
This study investigated the influence of guidance and counseling on choice of business subjects among secondary school students in Gombe state. Two specific objectives, two research questions and two null hypotheses were raised. Survey research design was adopted for the study. The population of the study was 21,465 secondary school students and 377 of them were randomly used for the study. Four rating scale structured questionnaire titled Choice of Business Subjects among Students (CVSS) constructed by the researcher were used for data collection. Data collected were analyzed using benchmark score of 2.5 and above for agree while simple logistic regression was employed in the test of the two null hypotheses at 0.05 alpha level of significance. The study revealed among others that guidance and counseling has influence on choice of business subjects among secondary school students in Gombe state. In addition in contributed on gender disparity of students choice in business subjects. The resultant effect is that most secondary school students perceived that business subjects are either meant for academic misfits or female students. Based on the outcome of the study, the researcher recommended among others that teachers, especially those counseling students should help to instill in students the positive attitude towards business subjects, this will develop in them interest and choice of business subjects at secondary school level.
\end{abstract}

Keywords: - Guidance, Counseling, Choice, Business, Subjects, Students.

DOI: $10.7176 /$ RHSS/9-12-20

Publication date: June $30^{\text {th }} 2019$

\section{Introduction}

Business subjects are aspects of vocational and technical education programme designed to guide, support, or create practice in changing workplaces for their self reliance. This increased interest of the role of business subjects on the economy of the country has triggered policy makers into giving greater importance to business subjects in Nigeria. It is commonly believed that the introduction of business subjects is an imperative that will make a positive contribution to improving the business subjects orientation of students, leading to the acquisition of skills, creativity, confidence, drives and courage, job creation among the school leavers. The educational programme has been identified globally as essential tool that equips recipients with requisite skills required for work that enables the recipients to remain relevant in the face of increasing global competition in the labour market. The foundation of business technical education is based on philosophy which was mainly established for selfemployment and self-reliance of the individual(s) who partake in it. Generally, business subjects at secondary school level which include business studies, economics, commerce, marketing and principles of accounting have positive image in the growth and development of the youths and nation at large.

Guidance can be defined as the process of helping an individual to develop and accept an integrated and adequate picture of himself and of his role in the world of work, to test this concept against reality and to convert it into reality with satisfaction to himself and benefit to the society in general. In school, the role of guidance service of creating awareness by providing information needs for students cannot be overemphasized. Specifically in secondary school, guidance service is responsible for making students to see and explore their unlimited endowed options. It is indisputable fact that the major service areas of guidance service is to assist students in their choice of career and prepare for an occupation that is compatible with their interests and aptitudes. Adamu and Mohammed (2013) reported that guidance assumed significant responsibilities of informing students about job opportunities by creating awareness necessary for students to look for work, secure an appropriate job and move ahead in careers. The role of guidance in school according to National Policy on Education (2012) is to:- (i) increase students understanding, interests and values; (ii) enable students to identify those occupational areas that suit them; (iii) help students to develop an acceptable self-image and realistic attitude towards academic achievements as a necessary prelude to vocations/careers; (iv) motivate oriented towards appropriate career and orientation as well as creation of awareness of opportunities; and (v) inculcate in students the dignity of labour. It therefore follows that the role of the guidance is crucial for career choice and development of secondary school 
students. Hence it is not over statement to say through guidance service students overwhelming ignorance and difficulties of career choice and personality maladjustment will be sensitized and eliminated to some extent.

Guidance service plays a key role on career exploration of students. Through guidance, students gain a wider acquisition not just of knowledge and skills, but of an understanding about how to use them. In this context, the mission of career guidance has widened and become part of lifelong learning an even acquired higher profile as countries adopt more active approaches to unemployment and to welfare reform. This explains why OECD (2003) argued that the service of guidance units plays a key role in helping students to decide on a job or a course and broader development of career management skills. Sari (2010) posits that school counsellor is an important team player or part of the educational leadership team that provides valuable assistance to students. Considering the role of guidance service on choice of subjects and career plans of secondary school students prompted the researcher to investigate the influence of guidance service on attitude and choice of business subjects among secondary school students in Gombe State.

\section{Statement of the Problem}

Business subjects are recognized universally as the tool for solution to socio-economic problems of the world. Through business subjects problems of poverty, unemployment and security will be solved to some extent. This explains why developed nations such as America, China, Russia and Britain aspire towards equipping youths with business skills and training for their self-reliance. The aim of business subjects according to National Policy on Education (2012) is to: - (i) provide trained manpower in applied science, technology and commerce particularly at sub-professional grades; (ii) provide technical knowledge and business skills necessary for agriculture, industries, commercial and economic development; (iii) give training and impact the necessary skills leading to the production of craft-men, technicians and other skilled personnel who will be enterprising and self-reliant; (iv) enable our young men and women to have intelligent understanding of the increasing complexity of technology; and (v) give an introduction to professional studies in engineering and other technologies.

Despite the laudable importance of business subjects, the researcher observed that the general behaviour of students towards the subjects is not impressive and encouraging. It is not a hidden fact that the need for introducing business subjects into secondary school curricula is not felt as students have negative perception towards the subjects. By now, secondary school students in Nigeria ought to embrace the subjects, offer it in their school and even practice it upon graduation, but reverse is the case. In Nigeria, it is unfortunate to mention that business subjects have remained a subordinate discipline in terms of societal recognition, interest and its choice among secondary school students. It is dismal that in Nigeria students believe that business subjects are reserved for students who cannot succeed in areas like science or social science. According to Azubuike (2011), students and even counselors seem not to understand what business subjects is all about and consequently, develop some contempt and aversion for the subjects and continue recommending it to students that are below average. Similarly, Adamu and Mohammed (2013) posit that most school counselors believe that commercial subjects such as commerce, economics and principles of accounting are meant for academic misfits and down trodden students with low talent and abilities needed for students to cope with serious educational challenges. These urged the researchers to investigate: (1) the influence of guidance and counseling on the choice of business subjects among secondary school students in Gombe state; and (2) the influence of guidance and counseling on gender disparity on choice of business subjects among secondary schools in Gombe state.

\section{Research Questions}

The study answered the following research questions:-

1. What is the influence of guidance and counseling on the choice of business subjects among secondary school students in Gombe state?

2. What is the influence of guidance and counseling on gender disparity on choice of business subjects among secondary school in Gombe state?

\section{Research Hypotheses}

In line with the objectives of the study, the following hypotheses are formulated and tested by using simple regression at 0.05 level of significance

1. Guidance and counseling have no significant influence on the choice of business subjects among secondary school students in Gombe state.

2. Guidance and counseling have no significant influence on gender disparity on choice of business subjects among secondary schools in Gombe state.

\section{Methodology}

Survey design method was used for the study. The population of the study was 21,465 SS I secondary school 
students in public secondary schools in Gombe state. The researcher used 377 students as recommended by Krejices and Morgan (1970).

Four rating scale structured questionnaire titled Choice of Business Subjects among Students (CVSS) was used for data collection. The questionnaire consists of twelve (12) item statements using six questionnaire items to answer each research question and testing of hypothesis. The respondents were required to indicate their perception by ticking or putting across after each statement of their choice under the columns "SA" (strongly agree),"A" (agree),"D” (disagree) and “SD” (strongly disagree)

The instrument used was first subjected to face validity test whereby two experts examined it and made useful suggestions towards its amendments, so based on their suggestions, the items on the questionnaire were either amended or substituted with others. The questionnaire was subjected to pilot study through test -retest treatment using Pearson Coefficient of Correlation formula. The pilot study gave reliability coefficient of 0.76 . Uzosike (2008) suggested that reliability co-efficient of a questionnaire should not be less than 0.05 . This value implies that the instrument is valid for studies of this nature.

The researcher personally administered the instrument to the respondents assisted by four research assistants. The respondents were required to fill the questionnaire based on the extent of their agreement or disagreement. Completed questionnaire were subjected to statistical analysis using an index mean score and standard deviation to answer the research questions. An index mean score of at least 2.5 was used as a criteria for agree while regression was used in the test of the null hypotheses at 0.05 level of significance. In the test of the null hypotheses, where the probability value was greater than 0.05 , the null hypotheses was retained. On the other hand, where the probability value was less than 0.05 , the null hypotheses was rejected.

\section{Results of the Study}

Analysis of data used to answer the research questions is as presented in Table 1 and 2

Research Question One:What is the influence of guidance and counseling on the choice of business subjects among secondary school students in Gombe state?

Table 1: Mean and Standard Deviation on opinions of students on influence of guidance and counseling on their choice of business subjects among students

\begin{tabular}{rrlllll}
\hline & Total & & Mean & & Std. dev & Remark \\
\hline Responses & Agree & Disagree & Agree & Disagree & & \\
\hline 2621 & 1855 & 766 & 2.8 & 1.2 & 0.581 & $2.8>2.5$ \\
\hline
\end{tabular}

The cumulative responses of respondents used to answer research question one revealed the cumulative score 2621 with score of 1855 for those who opined that guidance and counseling has influence on the choice of business subjects. Those that had contrary opinion scored 766 with mean score of 2.8 and 1.2 respectively in favour of agree. From the result of the analysis the calculated value was found to be greater than the benchmark for agreed $(2.8>2.5)$. Based on the result, it was concluded that guidance and counseling has influence on the choice of business subjects among secondary school students in Gombe state.

Research Question Two:What is the influence of guidance and counseling on gender disparity on choice of business subjects among secondary school in Gombe state?

Table 2: Mean and Standard Deviation on opinions of students on influence of guidance and counseling on gender disparity on the choice of business subjects among students

\begin{tabular}{|c|c|c|c|c|c|c|}
\hline & Total & & ean & & Std. dev & Remark \\
\hline Responses & Agree & Disagree & agree & Disagree & & \\
\hline 1684 & 1182 & 502 & 2.8 & 1.2 & 0.309 & $2.8>2.5$ \\
\hline
\end{tabular}

Analysis of data used to determine the influence of dependent on independent variable is as presented in Table 2. From the table cumulative score of 1684 was obtained with score of 1182(2.80) for those who opined that guidance counseling have influence on gender disparity on the choice of business subjects among students. Those that disagree scored 502 (1.20) with standard deviation of .309. Based on the outcome of the analysis, the calculated value was found to be greater than the benchmark for agree $(2.80>2.5)$, hence the result shows that guidance and counseling has influence gender disparity on the choice of business subjects among secondary school students in Gombe state.

\section{Test of Hypotheses}

Results of the analysis of data used to test the null hypotheses were as presented in Table 3 and 4.

HO1: There is no significant influence of guidance and counseling on the choice of business subjects among secondary school students in Gombe state. 
Table 3: Regression analysis of influence of guidance and counseling (G\&C) on choice of business subjects (CBS) among secondary school students

\begin{tabular}{cccccccccc}
\hline Model & B & Std. Error & T & Sig. & Beta & r-crit & R & R Square & Adjusted R Square \\
\hline G\&C (Constant) & 5.694 & .648 & 8.787 & .000 & & & & & \\
& 0.053 & .015 & 3.665 & .001 & 0.622 & 0.088 & .860 & .740 & .696 \\
\hline
\end{tabular}

The regression analysis to test the influence of G\&C on CBS in Table 3 indicated an $r$ value .860 and at $\alpha=$ 0.05 . The summary of the analysis shows the constant value of 5.694 which indicates that the regression equation needs to be adjusted by 5.694 upward. The probability value was 0.00 while the R-square which was 0.74 signified that $74 \%$ of the variance that influence CBS was accounted by G\&C. The observed 0.860 was significant, this can also be seen in the $r$-cal found to be greater than the $r$-crit $(.0860>0.088)$. Based on the analysis it was concluded that G\&C has significant influence on CBS among secondary school students in Gombe state. The null hypothesis was therefore rejected.

$\mathbf{H O}_{2}$ : There is no significant influence of guidance and counseling on gender disparity on choice of business subjects among secondary school in Gombe state.

Table 4: $\quad$ Regression analysis of influence of guidance and counseling (G\&C) on gender disparity on choice of business subjects (GDCBS) among students

\begin{tabular}{cccccccccc}
\hline Model & B & Std. Error & T & Sig. & Beta & r-crit & R & R Square & Adjusted R Square \\
\hline G\&C (Constant) & 5.694 & .648 & 8.787 & .000 & & & & & \\
& 1.572 & .085 & 2.955 & .001 & 0.622 & 0.088 & .683 & .467 & .453 \\
\hline
\end{tabular}

Analysis of data used to test null hypothesis two shows the Constant Beta value of 5.694 with t-value of 8.787 for G\&C. Gender disparity on choice of business subjects (GDCBS) among students has 1.572 with t-value of 2.955 . The $\mathrm{R}$-cal was greater than the R-crit $(.683>0.088)$. The result shows the $\mathrm{R}^{2}$ value of .467 , indicating that $47 \%$ of the variance of students' choice of business subjects is attributed to G \& $\mathrm{C}$. The null hypothesis is therefore rejected.

\section{Discussion of the Findings}

The study revealed that guidance service in secondary schools in Gombe state has influence on the attitude of students towards business subjects. This confirms the study of Grubb, (2002) and Tricot (2002) highlighted that career guidance assumes an even higher profile as countries adopt more active approaches to unemployment and to welfare reform. Quek (2001) opined that guidance counsellors to develop an intergrated approach towards a client which includes knowledge of a client interests, abilities, talents, values, attitudes and personality. In sum, the career counsellor needs to be sensitive to the clients self-concept (and social psychological make-up). This means career counseling cannot be over-simplistic as fitting people to job specifications or vice versa. Salvaor in Sinjib (2011) opined the secret of good education consists in enabling the student to realize what are his talents and aptitudes and in what manner and to what extent he can best develop them so as to achieve proper social adjustment and seek right types of employment. The author added that guidance is the best subject that will provide assistance to students in deciding upon their future careers and other personal problems. It is on this background information that the researcher conducted a research work on the Imperative need to integrated career guidance to business subjects programme in Nigerian Tertiary Institutions.

The finding of research question two which was further affirmed by test of corresponding null hypothesis revealed that guidance service has significant influence on gender disparity on choice of business subjects among secondary school in Gombe state. This finding agreed with that of Angeline (2011) who reported that the perceptions and attitude of teachers teaching in school may be discouraging. The authors observed that attitude often make boys to drop commercial subjects to take science subjects that will make them to read courses like medicine, engineering, architecture and so on, while girls will only study to become secretaries, teachers, and businessmen. This perception or attitude of teachers inform how they teach and attend to the girls in classes especially mathematics and science, and these end up affecting the performance of the girl child. Sanjib (2011) who highlighted that career counseling gives an understanding to the students the importance of one academic potential and gender Azubuike (2011) revealed that interest, gender, socio-economic status, the qualification of teachers' instructors and guidance counseling were the five major factors that influence students in the business subjects in schools. Adamu and Mohammed (2013) attributed this stereotype to teachers, school guidance and counseling as well as the perception of students. The authors observed that male are considerably less interested in business subjects than females, and this can be attributed to the stereotype that it is only for the females or "tom girls". Research by Payam (2013) also shows that teachers more especially guidance units have the conception that commercial subjects is better for female students. 


\section{Conclusion}

Generally the research work shows that significant relationship exist between guidance and counseling and resultant negative effect of choice of business subjects among secondary schools in Gombe state. Based on the information provided of students, most of them perceived business subjects are meant for academic and social misfits, problematic and lawless students. By implication these made most secondary school students to prefer science subjects to business subjects.

\section{Recommendations}

Based on the findings of the study, the researchers recommended that:-

1. Teachers, more especially guidance units should develop positive attitude towards business subjects and stop recommending business subjects to academic and social misfits students

2. Government and stakeholders in education should organize public awareness programmes on importance of business subjects to students. This will assist in curbing the negative attitude of male students towards the subjects.

\section{References}

Adamu, I. (2010). Needs of Integrating Career Guidance to Business Education Programme in Nigerian Tertiary Institutions A.B.U Journal of Educational Psychology and Counseling . 1(2) 40-47.

Adamu, I. \& Mohammed, I.A. (2013). Analysis of Roles of Guidance Service on Students' Attitude towards Vocational and Technical Subjects (VTS) in Secondary School in Nasarawa State. Journal of Vocational Education and Technology (JOVET). A Publication by Faculty of Vocational and Technical Education Ignatius Ajuru University of Education Port Harcourt. 10 (1 \& 2) 1-13.

Angeline N. (2011), "Girls, Schools and Statistics Education in South Africa", First Africa Young Statisticians conference, [Online] Available: http://www.statssa.gov.za/ycs.

Azubuike, O. C.(2011). Influential Factors affecting the attitude of students Towards Business/Technical subject in secondary schools in Southeastern Nigeria. Journal of Educational and social research, 1 (2). From citeseerx.ist.psu.edu/viewdoc/download?

Demand V. (2008) Objectives of Business Guidance: From http://twitter.com/ehow

Federal Ministry of Information (2012), National Policy on Computer Education, Lagos, FMI.

Grubb, D. Lum, P. and Morgaine H. (2002) Critical Issue: Developing an Applied and Integrated Curriculum: From http://www.avaonline.org/; Retrieved on $2 / 2$

Joel, L. N. (2014). Assessment of Attitudes of Secondary School Students Towards Business subjects and Training In Tanzania: Case Study Of Mpwapwa District. A Dissertation Submitted in Partial Fulfillment of The Requirements for the Degree Of Master of Science in Agricultural Education and Extension of Sokoine University of Agriculture. Morogoro, Tanzania. From ro.ecu.edu.au/cgi/viewcontent.cgi

Jubril A.H. (2010). Towards improving the standard of vocational and technical education in Nigeria. Journal of Business Educational Research and Development (JOBERD), Vol. 1 No. 1

Kennedy, O. O. (2012). Philosophical and Sociological Overview of Business Technical Education in Nigeria College Student Journal, 46 (2), 274-282. From http://eric.ed.gov/?id=EJ994216

Kerlinger, F. N., (2000). Foundations of behavioural research (5thed.), New Delhi: Holt, Rinehart and Winston.

Krejcie, R. V., \& Morgan, W. D., (1970).“Determining sample size for research activities”. Educational and psychological measurement, 30(3): 607-610.

OECD (2003), Beyond rhetoric: Adult learning policies and practices, Paris.

Payam Z. (2013) "Closing the Gender Gaps for Women in Science", Immpress Magazine.

Quek, A.H. (2001). Designing counselor education and training programmes for public tertiary institutions in Malaysia [Jenis rekabentuk dalam latihan dan pendidikan kaunselor di Malaysia]. Paper to be presented at National Seminar on Standardisation of Counsellor Education and Training in Malaysia, Kuala Lumpur, Malaysia.

Sanjib C. (2011) Career Counseling and Guidance for Students, Parents \& Working Executives: From http://careercounseling.blogspot.com/

Sari, E. (2010). School Counsellors Education with Observation in Schools. Procedia Social and Behavioural Science2(2010)3899-3903, Elsevier Publications Ltd.

Tricot, A. (2002). Improving occupational information. Paper prepared for the OECD Career Guidance Policy Review,Available from Internet.

From: http://www.oecd.org/dataoecd/59/26/2485392.pdf.

Uzosike C. (2008) A study of the Relationship between Consumer behaviours and Acquisition of Household Equipment; Implication for Teaching Home Management is Senior Secondary Schools; Unpublished M.Ed Thesis, A.B.U. Zaria.

Watters, J. W. (2010). Career Decision Making Among Gifted Students: The Mediation of Teachers. Gifted Child Quarterly.54(3) 222-238- http://www.sagepub.com -retrieved 23-07- 2013. 